\title{
Syn to Post Rift Diapirism and Minibasins of the Central High Atlas (Morocco): The Changing Face of a Mountain Belt
}

\author{
Jaume Vergés ${ }^{1}$, Eduard Saura ${ }^{1}$, Grégoire Messager ${ }^{1}$, Juan Diego Martín- \\ Martin $^{1}$, Mar Moragas ${ }^{2}$, Philippe Razin ${ }^{2}$, Carine Grélaud ${ }^{2}$, Rémi Joussiaume ${ }^{2}$, \\ Manon Malaval ${ }^{3}$ and David W. Hunt ${ }^{3}$
}

${ }^{1}$ Institute of Earth Sciences Jaume Almera, CSIC, Barcelona, Spain

${ }^{2}$ ENSEGID - IPB, Bordeaux, France

3TPD RD, Statoil, Bergen, Norway

April 7, 2014 Monday 8:30 A.M. AAPG Annual Convention and Exhibition, Houston, TX

\begin{abstract}
The impact of diapirism on carbonate, mixed carbonate-clastic and clastic syn-post rift sedimentation is well expressed in Jurassic strata of the Moroccan Central High Atlas. Here elongate diapiric structures delimit platform margins and minibasins. In platform margin settings abrupt platform-basin transitions are delimited and punctuated by en-echelon diapiric structures can be traced over $40 \mathrm{~km}$ above buried normal fault systems. These diapirs are limited on one margin by relatively rigid platform carbonates. In contrast in more basinal settings the diapirs pierce more ductile basinal successions and are normally associated with classic diapiric structures. The ENE-WSW trending, 2000-km long Atlas Mountains, extending from Morocco to Tunisia, are classically regarded as a failed Mesozoic left-lateral transtensive rift arm subject to Alpine inversion, folding and thrusting. Internally, the Central High Atlas is constituted by long and continuous NE-SW and short NW-SE trending ridges forming a polygonal array. Triassic evaporite-bearing shales and associated evaporites crop out in the cores of the ridges that became the main source layer for the diapiric structures. The ridge array confines synclines in which distinctive halokinetic geometries (bed thinning, onlaps, truncations and/or sedimentary facies changes decreasing in paleowater depth towards the axis of the ridges) reveal numerous Early-Middle Jurassic diapiric-related mini-basins. The aim of this presentation is to contrast diapirs abutting and delimiting platform carbonates against those developed in more basinal settings. In addition, this new picture of the Central High Atlas, which we now recognize as an exceptionally well exposed natural laboratory for understanding the interactions between halokinesis, tectonics and sedimentation, depicts an analog for buried large salt-related provinces in both rift basins and continental margins.
\end{abstract}

AAPG Datapages/Search and Discovery Article \#90189 @ 2014 AAPG Annual Convention and Exhibition, Houston, Texas, USA, April 6-9, 2014 